\title{
FUNCTIONAL TRANSFORMATION OF WEST MORAVA VALLEY DISTRICT SETTLEMENTS
}

\author{
IVANA PENJIŠEVIĆ ${ }^{1}$, JOVAN DRAGOJLOVIĆ ${ }^{1}$
}

${ }^{1}$ Faculty of Sciences, University in Priština - Kosovska Mitrovica, Kosovska Mitrovica, Serbia

\begin{abstract}
The existing territorial layout and the current demographic situation in the settlements of West Morava Valley District during the late $20^{\text {th }}$ century and at the beginning of the $21^{\text {st }}$ century are the result of the synchronized action of the process of industrialization, deagrarization and urbanization. They conditioned the selective transformation of urban and rural space, which led to the concentration of the population in urban and suburban settlements and the depopulation of the rural part of the West Morava Valley District. Within the studied region, the hie rarchy of municipal centers, subcenters and communities of settlements was observed. Based on important theoretical and methodological assumptions and indicators, the paper analyzes the functional transformation of the settlements of West Morava Valley in the period between 1971- 2011. It was determined by certain quantitative methods that the changes went in the direction of reducing the share of purely agrarian settlements and increasing the share of industrial and service settlements.
\end{abstract}

Keywords: West Morava Valley District, Settlements Network, Business structures, Functional transformation of settlement.

\section{INTRODUCTION}

The area covered by the study represents the southernmost region of Peripannonian Serbia, while the time period of the research is 1971-2011. The reason for this is the fact that the most dynamic socio-economic transformation of the studied area occurred in the 1970's, caused by the influence of industrialization and urbanization. The West Morava River valley extends from west to east, including the valley of the West Morava River, from Požega in the west to Stalać in the east (Marković, 1970). The West Morava River valley is of composite character and consists of five depressions (Požega, Čačak - Kraljevo, Vrnjci, Trstenik, and Kruševac) and the same number of narrowings. This valley has great economic significance for Serbia (Lukić et al., 2018).

The West Morava Valley region was singled out on the basis of morphological and hydrological criteria of geographical regionalization, in which 230 dispersively distributed settlements were included in the research. The West Morava River valley is a large natural entity with an area of $2386.2 \mathrm{~km}^{2}$ with 429,439 inhabitants, according to the 2011 census (SORS, 2014). Therefore, about $6.0 \%$ of the population lives on $2.7 \%$ of the territory of the Republic of Serbia (Penjišević, 2016). Both absolute and relative majority of the population lives on its most spacious part of the altitudinal belt up to $300 \mathrm{~m}$ (Table 1).

Table 1. Hypsometric distribution of population and settlements in the West Morava River valley.

\begin{tabular}{|c|c|c|c|c|c|c|c|c|c|c|c|}
\hline \multirow{2}{*}{$\begin{array}{c}\text { Altitudinal } \\
\text { Belt }(\mathrm{m})\end{array}$} & \multicolumn{3}{|c|}{ Area } & \multicolumn{2}{|c|}{ Settlements } & \multicolumn{4}{c|}{ Population } & \multicolumn{3}{c|}{$\begin{array}{c}\text { Population Dens ity } \\
(\text { Pop/km sq) }\end{array}$} \\
\cline { 2 - 12 } & $\mathrm{km} \mathrm{sq}$ & $\%$ & Number & $\%$ & Number & $\%$ & Number & $\%$ & 1971. & 2011. \\
\hline$<300$ & 1265.4 & 53.0 & 137 & 59.6 & 296,958 & 80.3 & 379,284 & 88.3 & 234.7 & 299.7 \\
\hline $300-500$ & 751.5 & 31.5 & 75 & 32.6 & 63,866 & 17.3 & 45,953 & 10.7 & 85.0 & 61.1 \\
\hline$>500$ & 369.0 & 15.5 & 18 & 7.8 & 8,886 & 2.4 & 4,202 & 1.0 & 24.1 & 11.4 \\
\hline Total & 2386.2 & 100.0 & 230 & 100.0 & 369,730 & 100.0 & 429,439 & 100.0 & 154.9 & 179.9 \\
\hline
\end{tabular}

Source: Comparative Population Overview 1948-2011. Data by settlements, vol. XX, SORS, Belgrade, 2014; Real Estate Cadastre Service of the Republic of Serbia; Topographic. Map 1:300.000, list Kragujevac, 1988; Author's processing.

In the altitude zone up to $300 \mathrm{~m}$ above sea level, which covers $53.0 \%$ of West Morava Valley, there are 137 settlements (Table 1). In 1971, there were 296,958 inhabitants $(80.3 \%$ of the population), and in 2011 this number rose to 379,284 (88.3\%). In the altitude zone up to $300 \mathrm{~m}$ above sea level, all regional centers of West Morava Valley (Čačak, Kraljevo, Kruševac, Požega,
Vrnjačka Banja and Trstenik) are located, as well as other population-wise largest and functionally most important suburban settlements in the region. The concentration of population in this altitude zone arose as a consequence of industrialization in the mentioned city centers, but also as an intensive decline in the number of inhabitants in the higher zones of the studied region. 


\section{MATERIAL AND METHODS}

In this paper, the typological method and the method of the Horst-Ferre triangle are used. The application of the typological method is extremely important in the research of settlements, because it is possible to single out relatively homogeneously structured settlement systems and subsystems, with similar functional development laws. The typological method of settlement classification has a long tradition in the Serbian geographical school. As early as the beginning of the $20^{\text {th }}$ century, Cvijić's anthropogeographical conception laid the foundations for a systemic-structural approach, which is reflected in various types of typological classification of settlements (Antić, 2015). Grčić (1999) made a significant contribution to the functional systematization of settlements, through the elaboration of methodological settings of the typological classification of settlements (Dragojlović et al., 2017). Spatialdemographic and socio-economic specifics of the settlement transformation of the West Morava Valley indicate the possibility of applying the typological classification method, as a starting point for considering changes in employment of the working population by activity sectors (Tošić, 2012). Within the studied region, the hierarchy of municipal centers, sub-centers and communities was observed.

Another method used in the paper is the Horst-Ferre triangle method, which is a graphical representation of the population activity structure. The Horst-Ferre triangle method implies the selection of nine types of settlements based on the participation of individual sectors of activity in the contingent of the population that performs the occupation (Tošić, 1999). It is represented by an equilateral triangle whose sides are divided into sections indicating the percentages of primary, secondary and tertiary activity. The inside of the diagram is divided into types denoted by a combination of numbers and letters. The functional type of settlements will be defined in the intersection of three lines, each of which has the value of a certain sector activity (Matijević, 2009). Due to the availability of the necessary data, the Horst-Ferre triangle method is fully applicable for the functional transformation of the West Morava Valley settlements analysis (Figure 1). The functional type of settlement is determined on the basis of the share of primary, secondary and tertiary sector activity in the total population performing occupation (Davies, 1967). The threshold for determining dominant belonging to a certain sector of activity is $60 \%$ (Table 2).

\section{RESEARCH RESULTS}

The dynamic functional transformation of urban and rural settlements in The West Morava River valley has been present since the mid- $20^{\text {th }}$ century up to today, when under the influence of the process of industrialization and urbanization, the key features of this region. Carriers of regional development were the city centers - Kraljevo, Čačak, Kruševac, Požega, Trstenik i Vrnjačka Spa. There along with the rapid development of industry, a concentration of population and development firstly of secondary, and then tertiary and quaternary activities.

The network of settlements in West Morava Valley belongs to the category of underdeveloped, with a pronounced disproportion between the level and speed of development of the above-mentioned urban settlements on one side and hillymountainous settlements on the other. Some rural settlements from territory City of Čačak (Vidova, Međuvršje, Prislonica), City of Kraljevo (Vitanovac, Ratina, Mataruge, Progorelica) and City of Kruševac (Maskare) developed certain functions at the beginning of the second decade of the $21^{\text {st }}$ century, but they are still insufficient to establish an even regional redistribution of the population's economic activities of West Morava Valley. In nonagrarian as well as agrarian settlements of West Morava Valley, the structure of the active population largely corresponds to the structure of their functions. Deviations, conditionally speaking, can be in those settlements where the participation of daily migrants is higher. Accordingly, the criterion for functional transformation should include the function of employment as well as the centrality of the settlement (Đurkin, 2018).

Changes in the functional structure of settlements are easiest to monitor on the basis of indicators of changes in the activity structure of the active population that performs certain occupations (Tošić, 1999). According to this model, nine functional types of settlements have been differentiated in the territory of the West Morava Valley (Table 2).

By applying the mentioned methodology, from 1971 to 2011, it was concluded that the degree of functional transformation of the settlement of West Morava Valley was growing slowly. Until the middle of the $20^{\text {th }}$ century, the functions of the settlements of the studied region completely depended on the way of using land and water resources, so the available natural potentials and low level of economic development conditioned their agrarian character. The functional transformation of the settlements of West Morava Valley, conditioned by the industrial development that began in the 1960 s, greatly reduced the dependence of the rural economy on the natural potentials in the area of the settlement. The process of industrialization in them initiated the transfer of the rural agricultural population to non-agricultural activities. Thus, the structural changes are reflected in the gradual decrease of the share of the primary sector, on the one hand, and increase of the secondary and tertiary sectors, on the other.

The number of agro-industrial settlements from 1971 to 2011 increased from 19 to 34 , and the structural changes in them are reflected in the gradual decrease in the share of the primary and the increase in the secondary sector of activity. In 1971, settlements near the main city centers, whose significant share of the population was employed in the industrial plants of Kraljevo (Adrani, Žiča, Vrba, Zaklopača, Konarevo, Šumarice), Požega 
(Bakionica, Gorobilje, Prijanovići), Kruševac (Begovo Brdo and Čitluk) and Čačak (Međuvršje) belonged to this functional type. Forty years later, the number of agro-industrial settlements increased by 15 , with the share of those which are active in the primary sector ranging from $38.8 \%$ (Čukojevac on the Gledic Mountains from territory City of Kraljevo) to $59.6 \%$ (Banjica on Jelica from territory City od Čačak).

Table 2. Methodology for distinguishing functional types of settlements in the West Morava Valley in 1971 and 2011.

\begin{tabular}{|c|c|c|c|c|}
\hline Functional type of settlements & Criteria & 1971. & 2011. & Change \\
\hline Agrarian & $\mathrm{I}>\mathrm{or}=60 \%$ & 179 & 73 & -106 \\
\hline Agro-industrial & $\mathrm{I}>\mathrm{II}>\mathrm{III}$ & 19 & 34 & +15 \\
\hline Agro-service & I $>$ III $>$ II & 0 & 7 & +7 \\
\hline \multicolumn{2}{|c|}{ Agrarian total } & 198 & 114 & -84 \\
\hline Industrial & II $>$ or $=60 \%$ & 12 & 23 & +11 \\
\hline Industrial-agrarian & II $>$ I $>$ III & 14 & 22 & +8 \\
\hline Industrian-sevice & II $>$ III $>$ I & 4 & 59 & +55 \\
\hline \multicolumn{2}{|c|}{ Industrial total } & 30 & 104 & +74 \\
\hline Service & III > or $=60 \%$ & 0 & 0 & 0 \\
\hline Service-agrarian & III $>$ I $>$ II & 0 & 1 & +1 \\
\hline Service-industrial & III $>$ II $>$ I & 2 & 12 & +10 \\
\hline \multicolumn{2}{|l|}{ Service total } & 2 & 13 & +11 \\
\hline
\end{tabular}

Source: Tošić (1999); Federal Bureau of Statistics, Beograd, 1974, SORS, Beograd, 2014;Penjišević (2016)

In 1971, there were no settlements in the West Morava Valley, and in 2011 there were seven settlements: Vapa, Donja Gorevnica, Donja Trepča, Gornja Trepča, Baluga Ljubićska and Mrčajevci on the territory of the City of Čačak and Varvarin

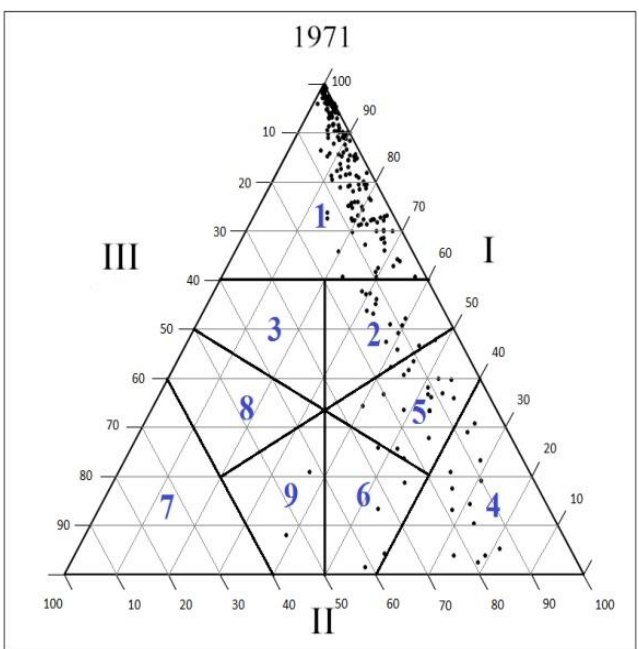

Village. These are well-connected settlements with the centers, which have developed a tourist-catering, educational and health function in the meantime.

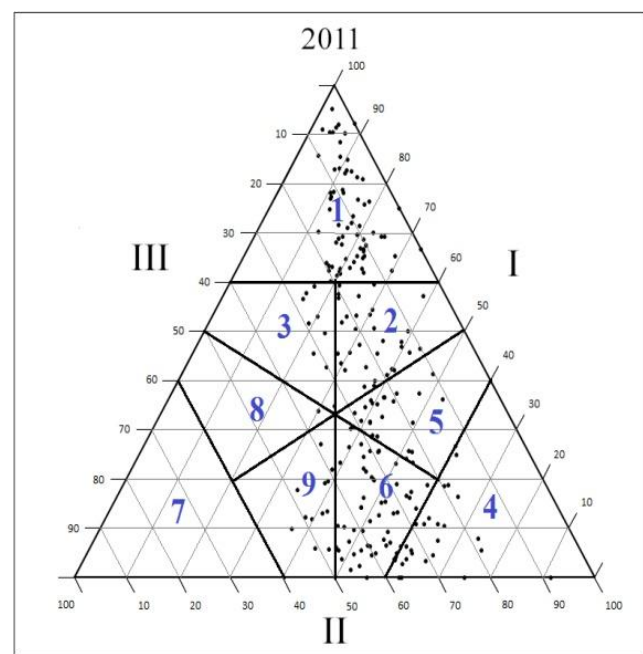

Figure 1. Changes in functional types of settlements in West Morava Valley in 1971 and 2002 by the Horst-Ferre triangle method

Legend: 1. Agrarian; 2. Agro-industrial; 3. Agro-servicing; 4. Industrial; 5. Industrial-agrarian; 6. Industrial-servicing; 7. Servicing; 8. Servicingagrarian; 9. Servicing-industrial.

The biggest functional changes are evident in the vicinity of the gravity centers of Čačak, Kruševac and Kraljevo, as well as in settlements along important roads such as the West Moravian and Ibar highways. The expansion of the influence of urban settlements intensified the daily mobility of the population, the restructuring of activities as well as the concentration of functions, which indirectly or directly reflected on the differentiation of the settlement network into peri-urban and agrarian parts.

In 1971,198 settlements or $86.1 \%$ of all settlements in West Morava Valley were of the agrarian type (Figure 2). Most

settlements with over $60 \%$ active in the primary sector of activity were from the municipalities of Trstenik (49 out of 51 settlements), Čačak (47 out of 58) and Kruševac (31 out of 43). The studied region had an agricultural character in 1971, which is shown by the fact that 136 settlements had over $90 \%$ of the active population in the primary sector of activity. Such settlements were mostly located in the municipality of Trstenik (32), followed by Čačak (15), Kruševac (14), Kraljevo (6), while in the municipality of Vrnjačka Banja only the settlements of Vukušica and Otroci belonged to this category (Figure 2). 
The intensity of the process of deagrarization of West Morava Valley can be seen based on the data on the active population by activities from the 2011 census (Figure 3). Based on the given graphic contribution, it is evident that agrarian characteristics, where more than $60 \%$ are active in the primary sector of activity, retained only 73 settlements (31.8\%). This means that compared to 1971, 22 settlements in West Morava Valley have moved to a higher functional type (Table 2). The number of settlements where more than $90 \%$ were active in the primary sector in 2011 was reduced from 136 to 10 settlements, which and are the following: Brezovice and Premeća on the mountain Jelica (City of Čačak), Trgovište on Kotlenik (City of Kraljevo), Rajinac and Mala Sugubina on the Gledić Mountain (Municipality of Trstenik), as well as Lazarevac, Kamenare, Komorane, Globare and Ljubava on the northern edge of the Kruševac valley towards Temnić (Figure 3).

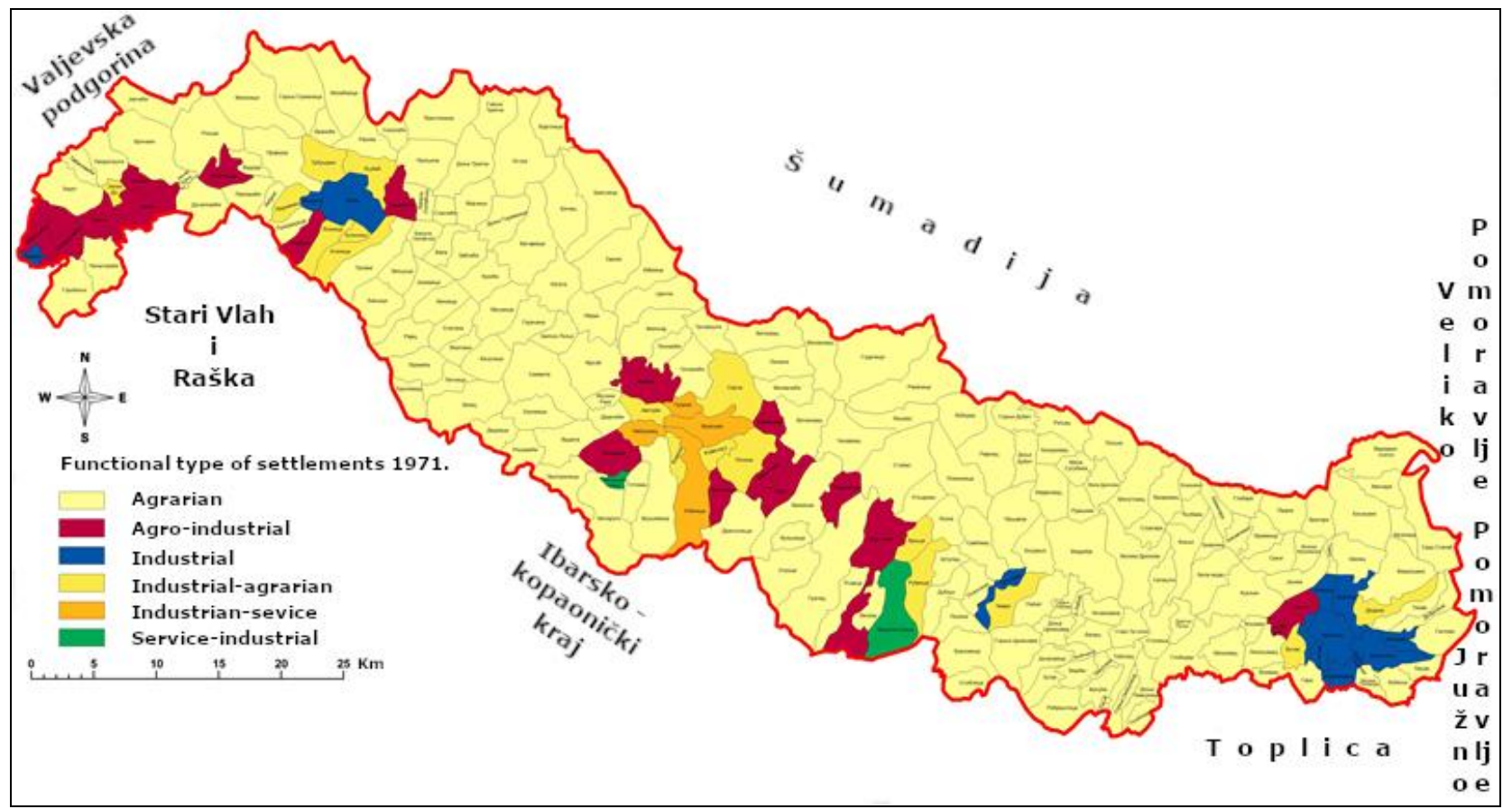

Figure 2. Functional type of settlements in West Morava Valley 1971. (Source: Federal Bureau of Statistics, Beograd, 1974; Map 1:300.000, list Kragujevac, 1988; Penjišević, 2016).

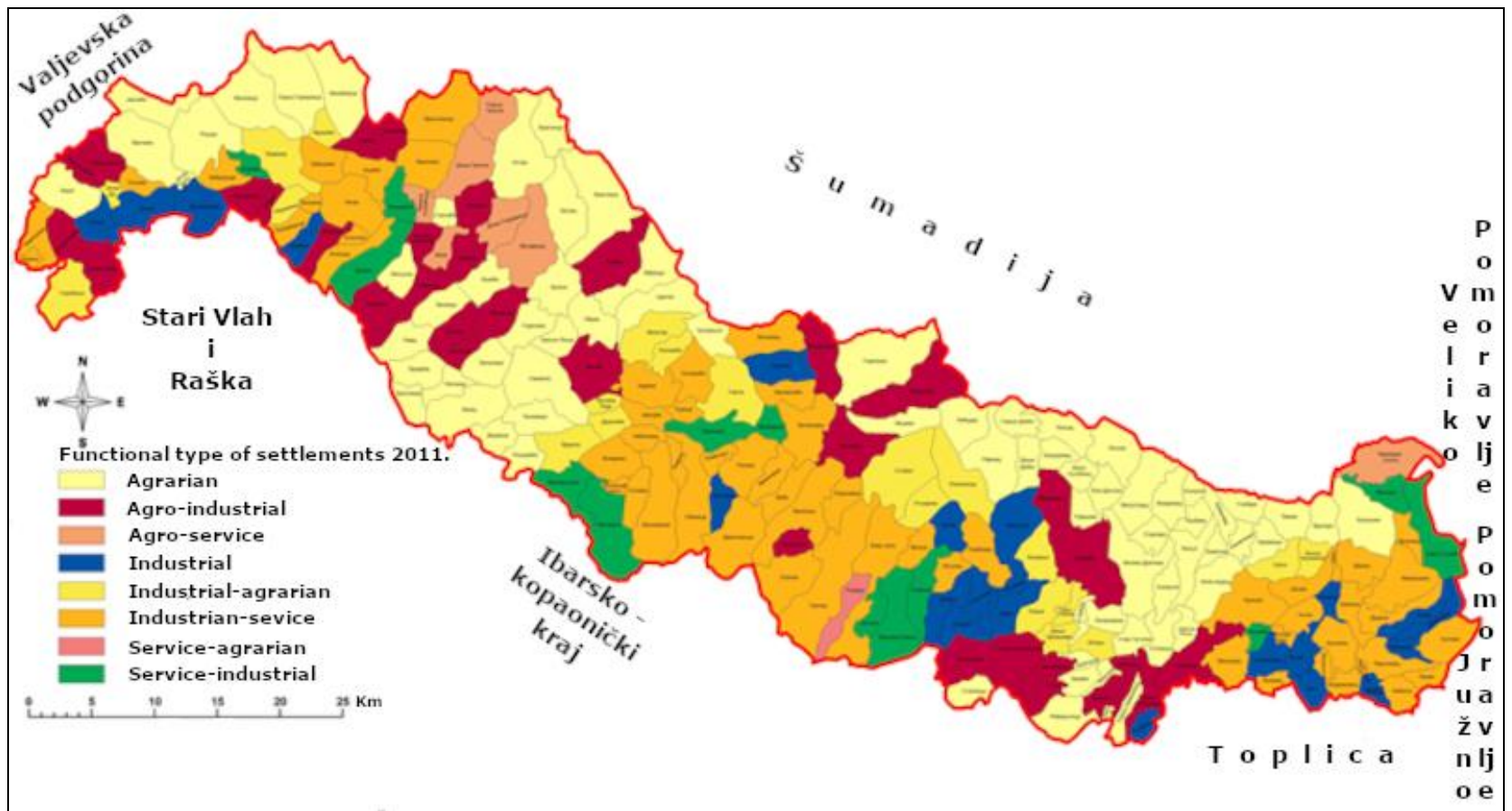

Figure 3. Functional type of settlements in West Morava Valley 2011. (Source: SORS, Beograd, 2014; Map 1:300.000, list Kragujevac, 1988; Penjišević, 2016). 


\section{DISCUSION}

By analyzing the results obtained by the research, it can be concluded that in the 1970s only urban centers and a few settlements in their spatial-influential sphere had a polyfunctional character, while other settlements of West Morava Valley were monofunctional. The territorial range of the functions of Čačak, Kraljevo and Kruševac is the strongest in the neighboring cities, i.e. municipal centers - Požega, Vrnjačka Banja and Trstenik. The functional development of municipal centers proved to be insufficient for the city to actively participate in the development processes of its surroundings, which was reflected in the demographic and functional characteristics of settlements in its surroundings, especially in peripheral parts (Stamenković \& Gatarić, 2007).

With the industrialization of the region, the majority of young and working-age people from the countryside are employed in urban centers and no longer live primarily from the land (Tošić \& Krunić, 2005). Compared to 1971, the impact of natural potentials on the functional type of settlements in 2011 decreased significantly. However, a part of the rural population from certain settlements such as Zaklopača, Konarevo, Zablaće, Trnava, Bakionica, Stopanje and others, who work in the city, but still live in the countryside, are engaged in agriculture as an additional source of income.

Although some West Morava Valley villages are nonagrarian according to the functional typology, agriculture has remained the main function of the population in the rural areas themselves. For example, the settlement of Progorelica (City of Kraljevo), located on the border of West Morava Valley and Donjeibarsko-Kopaonik region, in 2011 was classified as a highly non-agricultural settlement of the tertiary-secondary type, with only $5.8 \%$ of the active population in the primary sector (FBS, 1974; SORS, 2014; Penjišević, 2016). Most of the population of this Kraljevo settlement is employed in industrial plants in neighboring Konarevo and the rehabilitation center "Agens" in Mataruska Banja, but in the rural area of Progorelica in the alluvial plain of the Ibar, agriculture remained the main economic function. The situation is similar with the settlements of Vrba (6.6\% active in the primary sector) and Konarevo (9.4\%) in the territory of the City of Kraljevo, Jezdina (7.9\% in the primary sector) in the City of Čačak and Popina (11.0 \%) in Municipality of Trstenik, as well as with the settlements of Gari $(10.5 \%)$ and Veliko Golovode (10.9\%) on the territory of the City of Kruševac. This indicates that agricultural land, as the most significant natural potential of the rural parts of West Morava Valley, remained the basis of their regional development. Modernization of agriculture, introduction of agrotechnical measures, primarily mechanization, has influenced the reduction of the need for great manpower in agriculture.

Structural changes in the economy, caused by the process of industrialization and urbanization, directly affected the decrease in the participation of the active population in the primary and the increase in the participation of the active population in the secondary and tertiary sectors of activity. Indicators of the change in the structure of activities indicate that in West Morava Valley in the period from 1971 to 2011, the secondary sector developed most strongly. The number of settlements belonging to one of the three industrial types increased from 30 to 104 , with the number of industrial settlements increasing from 12 to 23 , industrial-agricultural from 14 to 22 and industrial-service type from 4 to 59 (Table 2).

The industry of West Morava Valley was largely based on the use of local raw materials (Stanisavljević, 1974). The economic and political situation in the country at the end of the 20th century, caused by the shutdown of a large number of factory plants, especially affected the functional development of West Morava Valley. Požega, Čačak and Kruševac have transformed from a predominantly industrial type into an industrial-service type. With the shutdown of the former giants of the metal industry, "Wagon Factory" and "Magnochrome", Kraljevo was transformed from an industrial-service to a serviceindustrial settlement. Thanks to the development of the functions of administration, health (Health Center "Studenica", Rehabilitation Center "Agent") and education (expansion of the network of primary and secondary schools and the opening of the Faculty of Mechanical Engineering), in 2011 the city on the Ibar River was $50.8 \%$ active in tertiary sector of activity. For forty years, Trstenik has retained the characteristics of an industrialtype settlement (62.4\% active in the secondary sector), while Vrnjačka Banja was a service-industrial settlement and still is, with $53.2 \%$ of employees in the tourism and catering sector (Penjišević, 2016).

In the activity structure of West Morava Valley, in addition to the secondary sector, tertiary development was developing intensively as well, where the number of service settlements increased from 2 to 13 (Table 2). In the analyzed period, one service-agricultural settlement developed - Rsavci from Vrnjačka Banja. This is a hilly-mountainous settlement, a significant part of which is located on the slopes of Goč, according to the functional typology in 1971, it belonged to the agrarian type, with $78.2 \%$ active in the primary sector. The transformation of the Rsavci settlement into a service-agrarian type in 2011 can be explained by the proximity of Vrnjačka Banja (3 km away), with a third of the rural population employed in hotels and catering facilities of this tourist center. From 1971 to 2011, the biggest changes took place in the type of service-industrial settlements, the number of which increased from 2 to 12. In the 1970's, those were the spa settlements of Vrnjačka and Mataruška Spa. In 2011, four settlements from the territory of the city of Kraljevo, (Kraljevo, Mataruge, Progorelica and Šumarice), three settlements from the territory of the City of Čačak (Trnava, Konjevići and Vidova), three settlements from the Municipality of Vrnjačka Banja (Vrnjačka Banja, Lipova and Ruđinci), as well as the settlement of Koševi from the territory of the City of 
Kruševac and Maskare from the Municipality of Varvarin belonged to this category as well (Figure 3 ).

\section{CONCLUSION}

Negative demographic processes and changes on the territory of The West Morava valley during the second half of the $20^{\text {th }}$ century conditioned not just the processes of deagrarization, depopulation and concentration but funkctional transformation of the settlements in this region is well. These changes contributed to the development of urban settlements of The West Morava valley, but also brought the stagnation of demographic potential of rural settlements. In order for the studied region to develop more evenly, it is necessary to invest in the development of all types of modern infrastructure, which is a very important factor for more progressive development of settlements in hilly and peripheral areas. An important aspect of the regional development of rural settlements in West Morava Valley is agriculture, which due to the improvement of this industry and all the conditions for successful development, could positively affect their future transformation. Thus, in order to encourage functional decentralization, it is necessary to develop microdevelopmental nuclei in which some industrial plants would be located, preferably adapted to local raw materials. The settlements of Gornja Trepca, Prislonica, Tavnik, Ladjevci and Milutovac have predispositions to become micro-development centers of the hilly and mountainous part of West Morava Valley, and must be valorized by planned measures. In order to transform these settlements into micro development centers, it is necessary to define the minimum production and central functions, which will be developed in them. Also, since West Morava Valley is a fruit and wine region, the opening of as many processing capacities as possible would have a positive effect in the villages on the outskirts of Požeška basin (Pilatovići, Loret), Čačanska basin (Prislonica, Gornja Trnava) and Trstenička basin (Jasikovica, Bučje), which would improve their hierarchical position in the settlement network of West Morava Valley.

\section{REFERENCES}

Antić, M. 2015. Tipologija seoskih naselja kao polazište revitalizacije ruralnog prostora Srbije. Zbornik radova sa 4. Kongresa srpskih geografa. Univerzitet u Beogradu: Geografski fakultet i Srpsko geografsko društvo. pp. 453458.

Bouldville, J. 1966. Problems of Regional Planning:Edinburgh University Press. Edinburgh.
Davies, E.K.D. 1967. Centrality and Central Place Hierarchy. Urban Studies, 4.

Dragojlović, J., Ristić, D., \& Milentijević, N. 2017. Spatial functional transformation and typology of the settlement system of Toplica district. The University Thought Publication in Natural Sciences, 7(2), 47-51. doi: $10.5937 /$ univtho $7-15574$

Đurkin, D. 2018. Tipovi promena populacionog razvoja naselja Južnog Banata (Srbija). Glasnik Srpskog geografskog društva, Beograd, 91(1), pp. 107-121.

Grčić, M. 1999. Funkcionalna klasifikacija naseqa Mačve, Šabačke posavine i pocerine. Glasnik Srpskog geografskog društva, Beograd, 79(1).

Lukić, T. Dunjić, J. Đerčan, B. Penjišević, I. Milosavljević, S. Bubalo-Živković, M. \& Solarević, M. 2018. Local Resilience to Natural Hazards in Serbia. Case Study: The West Morava River Valley. Sustainability 2018, 10(8), 2866, p. 1-16. https://doi.org/10.3390/su10082866

Marković, J. 1970. Geografske oblasti SFRJ. Zavod za uđžbenike i nastavna sredstva. Beograd.

Matijević, D. 2009. Spatial functional connection of the settlements Municipalities Stara Pazova with the urban sistem of Belgrade. Geographical institute Jovan Cvijić SANU. Belgrade.

Pavlović, M. \& Radivojević, A. 2009. Promene u funkcionalnim tipovima naselja opštine Sokobanja. Glasnik Srpskog geografskog društva, Beograd, 89(3), pp. 81-93.

Penjišević, I. 2016. Geografski aspekti regionalnog razvoja Zapadnog Pomoravlja. Univerzitet u Novom Sadu: Prirodnomatematički fakultet. Doktorka distertacija.

Republički zavod za statistiku. 2012. Popis stanovništva, domaćinstava i stanova 2011. u Republici Srbiji. Ekonomska aktivnost, podaci po naseljima. Beograd

Republički zavod za statistiku. 2014. Uporedni pregled broja stanovnika 1948-2011. Podaci po naseljima, knj. 20. Beograd

Savezni zavod za statistiku. 1974. Popis stanovništva 1971. Aktivno stanovništvo prema delatnosti, knj. 10. Beograd.

Stamenković, S. \& Gatarić, D. 2007. Čačak i njegov dnevni urbani sistem. Glasnik Srpskog geografskog društva, Beograd, 87(1).

Stanisavljević, D. 1974. Populacioni razvitak gradskih naselja u Zapadnom Pomoravlju. Univerzitet u Beogradu: Geografski fakultet. Beograd. Magistarski rad.

Topografska karta 1:300 000, list Kragujevac, 1988 Vojnogeografski institut, Beograd.

Tošić, D. 1999. Prostorno-funkcijski odnosi i veze u nodalnoj regiji Užica. Univerzitet u Beogradu: Geografski fakultet. Beograd. Doktorska disertacija.

Tošić, D. 2012. Principi regionalizacije. Univerzitet u Beogradu: Geografski fakultet. Beograd.

Tošić. D. \& Krunić, N. 2005. Urbane aglomeracije u funkciji regionalne integracije Srbije i Jugoistočne Evrope. Glasnik Srpskog geografskog društva, Beograd, 85(1). 